\title{
Development of the Ceramic Jewellry Industry for Necklace with Indonesian Batik Motifs
}

\author{
CD Mahendri ${ }^{1}$ PW Anggoro ${ }^{1, *}$ PK Fergiawan ${ }^{2}$ T. Yuniarto ${ }^{1}$ AP Bayuseno ${ }^{2}$ Jamari $^{2}$ \\ ${ }^{1}$ Departement of Industrial Engineering, Faculty of Industrial Technology, University of Atma Jaya Yogyakarta, Jl. \\ Babarsari 44, Yogyakarta 55281, Indonesia \\ ${ }^{2}$ Department of Mechanical Engineering, University of Diponegoro, Jl. Prof. Soedarto, SH., Tembalang, Semarang \\ 50275, Indonesia \\ *Corresponding author.Email: p.wisnuanggoro@gmail.com
}

\begin{abstract}
Currently, the national ceramic industry has developed products based on culture and the creative economy. This product is increasingly in demand by local and foreign consumers. Design development is carried out to face competition in the ASEAN Economic Community (AEC) so that there is no decrease in the quality and quantity of Indonesian ceramic export products. The effort that every ceramic industry player must always make is to innovate products by making new breakthroughs. Breakthroughs are no longer carried out conventionally but use advances in design technology based on computer-aided design (CAD) and reverse engineering (RE) which are often referred to as the Computer-Aided Reverse Engineering System (CARESystem). This paper will demonstrate the fabrication and assembly of ceramic pendant jewelry products with Indonesian batik motifs. The printed pattern master was made using manual printing technology at Naruna Ceramic Studio, Salatiga, Central Java. To obtain precision and accurate ceramic pendant products with a maximum shrinkage standard of $15 \%$ and a maximum dimension error of $2.00 \mathrm{~mm}$, the researchers provided a free angle to the product master and the mold pattern of $85-87 \%$. The results showed that the shrinkage from clay to ceramic products proved to be less than $15 \%$ so that the ceramic products could be processed by printing, burning, and glaze techniques. The average dimensional error is less than $2.00 \mathrm{~mm}$.
\end{abstract}

Keywords: Ceramic industry, Creative economy, Fabrication, Ceramic, Jewelry Ceramic.

\section{INTRODUCTION}

The creative industry is an industry that relies on and utilizes the skills, creativity and talents of an individual or group of people in creating prosperity and potential for employment [1]. The high consumer demand for manufactured products means that the creative manufacturing industry must be able to meet consumer demands that are varied, unique, precise, of quality and affordable. In order for the ceramic industry to survive in the current industrial era 4.0, it must be creative and innovative in designing, manufacturing and fabricating its products. This industry produces products, such as: floor tiles, sanitary ware, tile walls, tableware, technical tools made from ceramics and jewelry.

Computer Aided Design (CAD) is a technology related to the use of computer systems. This technology is used to assist in the creation, modification, analysis and optimization of designs. In CAD applications, computer graphics replace traditional engineering sketches and drawings used to visualize products and communicate design information [2]. The most basic role of CAD is to define design geometry. Complete and precise CAD data will make it easier for engineers to inspect the geometry, shape, surface and mass of objects to be designed $[3,4]$

Ceramic art is a branch of fine art that processes ceramic materials. This art is used to create a work of art that is traditional to contemporary [5,6]. Ceramics are the coverage for all objects made of clay, which undergo a heat or combustion process so that they harden. Ceramics can be made very strong, they can be made to resemble heavy lead or made as light as possible so that they float in water. The raw materials used to make ceramics are mostly clay and porcelain. This raw material goes through a process in such a way as to produce objects that can be used and can be displayed. In everyday life, ceramics are used as household utensils, displays, electronic devices, building ornaments [7-9]. 
PT. Gyan Kreatif Indonesia (GKI) is a company engaged in the handmade ceramic manufacturing industry with a focus on tableware products with glaze techniques combined with wood and plastic materials. One of the distinctive features of GKI compared to similar industries is the ability of the coloring technique (glaze) that competitors cannot compete with. However, this also has a significant negative impact when a number of customers want tableware or tile or jewelry products where the surface of the walls is given a motif with ornament relief with complex contour details. Sometimes these reliefs even have to depict local culture such as natural beauty, flora and fauna. The use of handmade ceramic technology cannot fulfill consumer demand because in the end it results in a very long design and manufacturing time for the master product and it is not precise if the product has to be mass-made. Making detailed, complex and artistic pendant ornaments on this paper is absolutely necessary for the application of artistic computer aided design (CAD) technology and computer aided manufacturing (CAM) with a CNC machine. In addition, the shrinkage factor is also an important success factor in the design, manufacture and fabrication of this jewelry ceramic. This factor becomes significant when products are printed in large quantities and must be precise. complex and artistic in this paper, it is absolutely necessary to apply artistic computer aided design (CAD) and computer aided manufacturing (CAM) technology with a CNC machine. Besides that, the shrinkage factor is also an important success factor in the design, manufacture and fabrication of this jewelry ceramic. This factor becomes significant when products are printed in large quantities and must be precise. complex and artistic in this paper, it is absolutely necessary to apply artistic computer aided design (CAD) and computer aided manufacturing (CAM) technology with a CNC machine. Besides that, the shrinkage factor is also an important success factor in the design, manufacture and fabrication of this jewelry ceramic. This factor becomes significant when products are printed in large quantities and must be precise.

This paper demonstrates the fabrication stages from the making of a master mold pattern to the assembly of a pendant into a patterned ceramic necklace with a maximum shrinkage of $15 \%$ and a maximum dimension error of $2.00 \mathrm{~mm}$. Master of ceramic products was obtained from previous researchers [10].

\section{METHOD}

The two main ingredients of the master ceramic pendant mold pattern in this paper are white gypsum and liquid clay (Figure 1). Gypsum with the Elephant brand was chosen as the main ingredient because it has light properties, soft but dense when compared to other materials. Generally, this material is in powder form, dissolves easily in water and is white or yellowish white in color (Figure 2). The stages of the process of making the master jewelry ceramic mold pattern can be presented in Figure 3. while the variations of the jewelry ceramic mold are presented in Figure 4. As a filling material for the liquid that is poured into this ceramic mold is clay, where the pouring process and the results can be presented in Figure 4. 5.

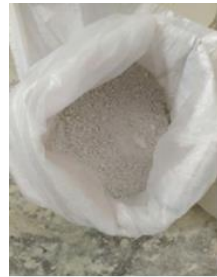

(a)

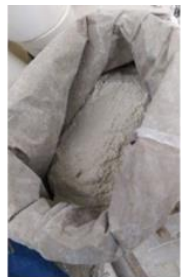

(b)

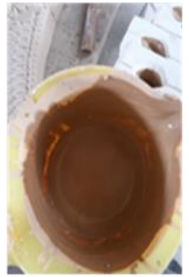

(c)

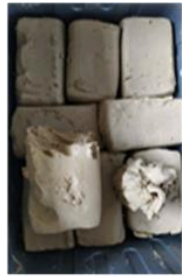

(d)
Figure 1 The main materials of the ceramic mold master: (a) white gypsum; (b) yellow gypsum; (c) liquid clay; (d) solid clay

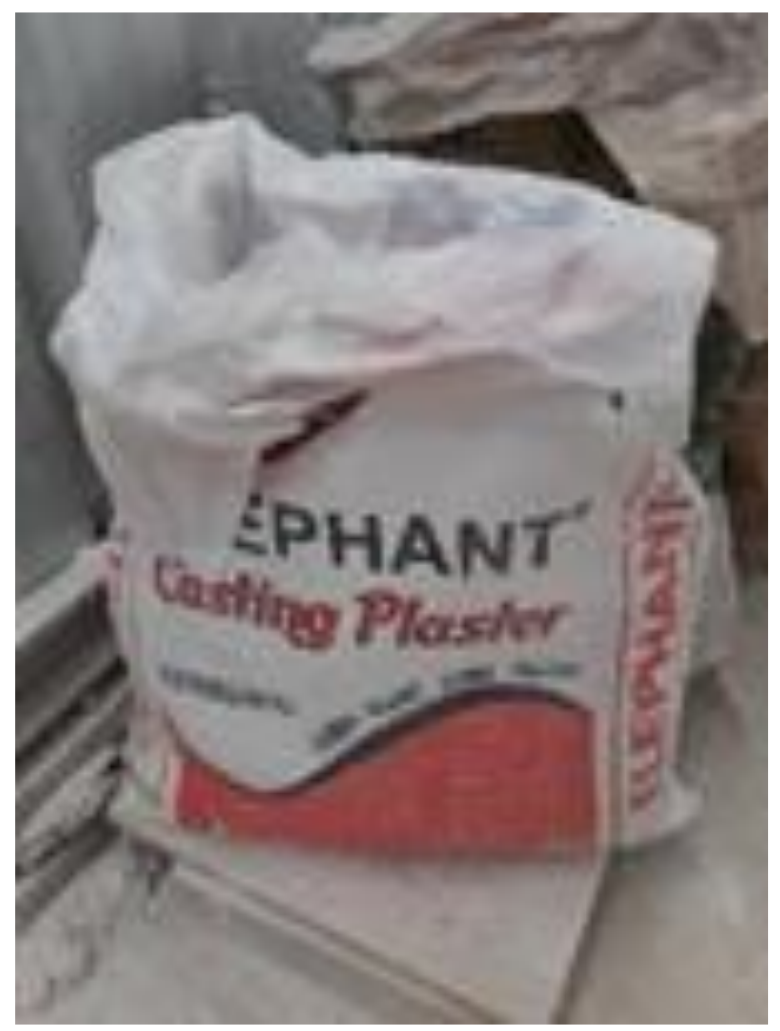

Figure 2 Elephant brand gypsum 


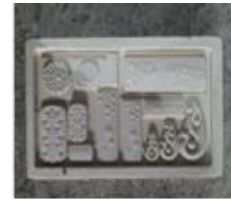

(a)

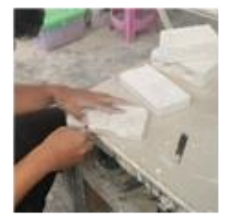

(j)
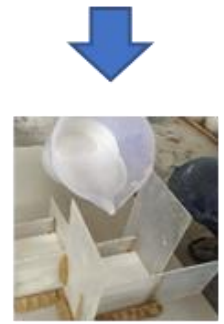

(k)

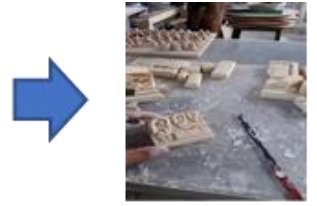

(b)
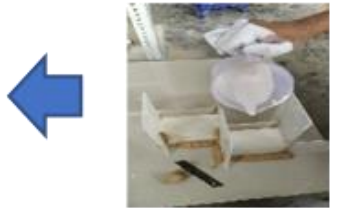

(i)

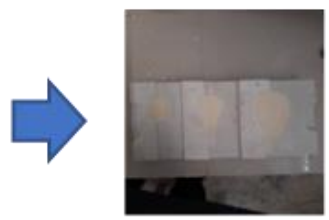

(1)

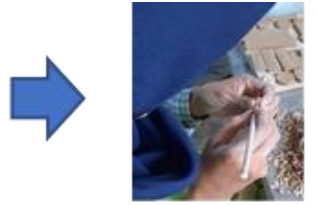

(c)

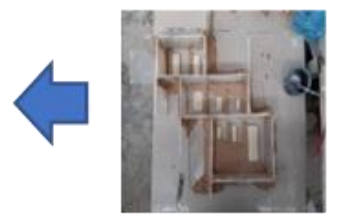

(h)

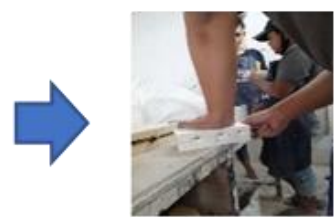

(m)

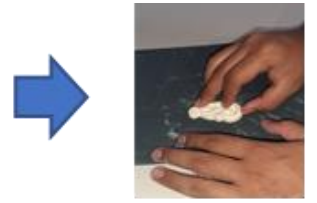

(d)

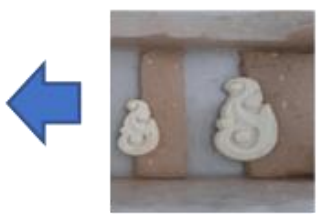

(g)

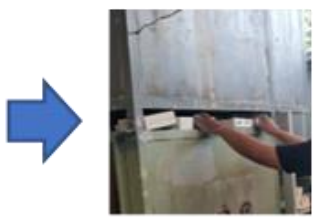

(n)

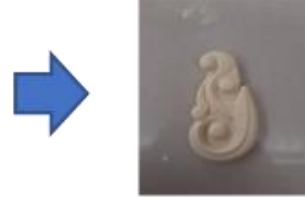

(e)
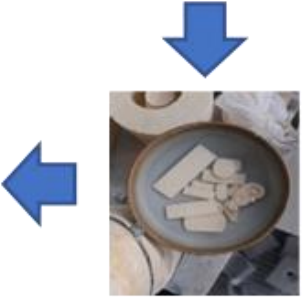

(f)

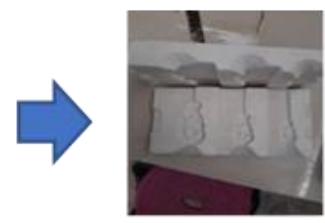

(o)

Figure 3. Stages of the process of making the master jewelry ceramic mold pattern: (a) CNC machining results; (b) cutting process according to the design pattern; (c) process master furnace product; (d) refinement of product master; (e) the master product of jewelry ceramic; (f) the product master immersion process; (g) the process of limiting the printed part; (h) side limiting process; (i) the process of pouring white gypsum dough; (j) furnace processes and pouring holes; (k) other side manufacturing process; (l) the process of removing the product master from the mold; (m) side and corner fireplace processes; (n) drying process; (o) printed jewelry ceramic products.

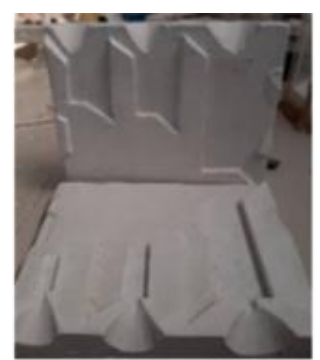

(a)

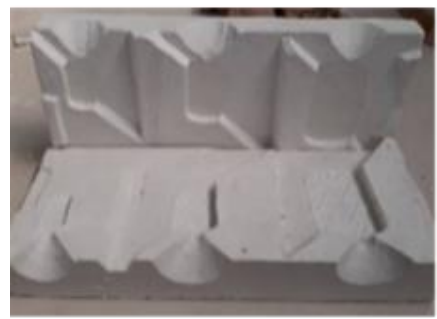

(d)

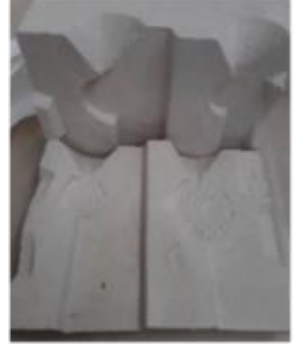

(b)

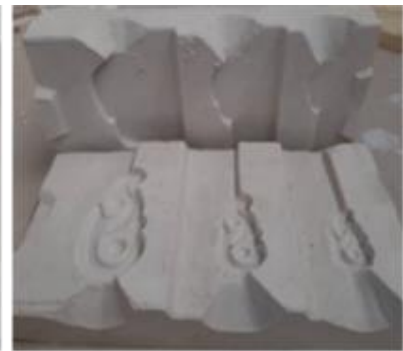

(c)

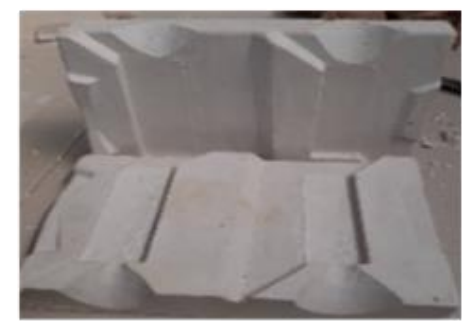

(e)

Figure 4 Variations of ceramic jewelry prints: (a) flora pattern; (b) geometric kawung; (c) megamendung; (d) geometric; (e) kawung flora pattern 


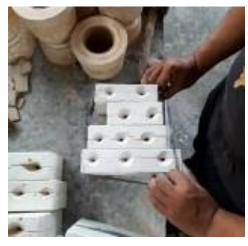

(a)

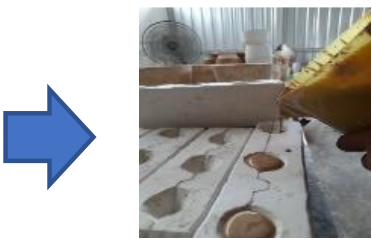

(b)

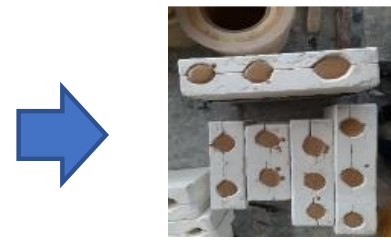

(c)

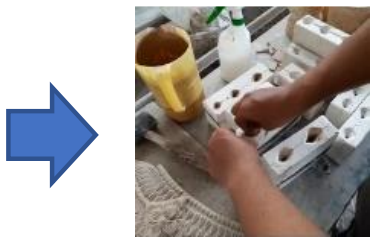

(d)
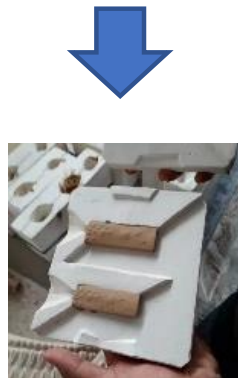

(e)

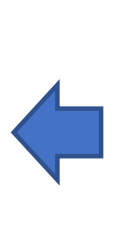

(g)

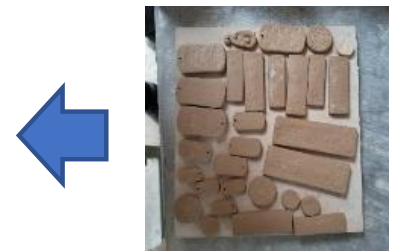

(f)

Figure 5 Pouring process: (a) the process of strengthening the mold with rubber; (b) liquid clay pouring process; (c) waiting process for absorption of water content; (d) the process of taking the remaining hardened clay; (e) mold opening process; (f) the process of drying the print; $(\mathrm{g})$ printed furnace process

After the wet clay from the pouring is formed, the next process is burning the ceramics. This process is carried out twice. The first burning is carried out to reduce the moisture content that is still in the clay so that it makes it easier for the coloring process. The second combustion is to bring out the color in the first combustion and this is often known as the "magic of ceramic" in the ceramic industry. The first combustion temperature is set at a temperature of $9000{ }^{\circ} \mathrm{C}$ to 10000 ${ }^{\circ} \mathrm{C}$ for 6 to 7 hours. The second combustion temperature is set at about $12300^{\circ} \mathrm{C}$ for 7 to 8 hours. An overview of the casting process in the ceramic industry can be presented in Figure 6

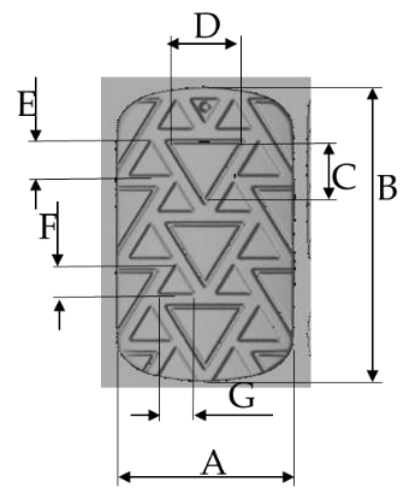

(a)

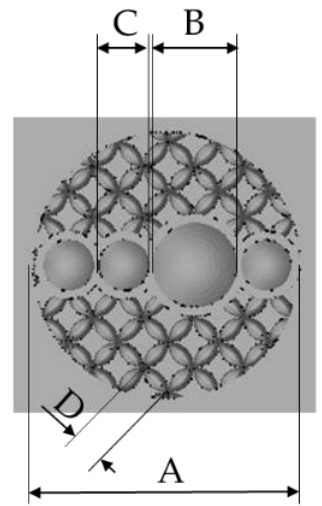

(b)

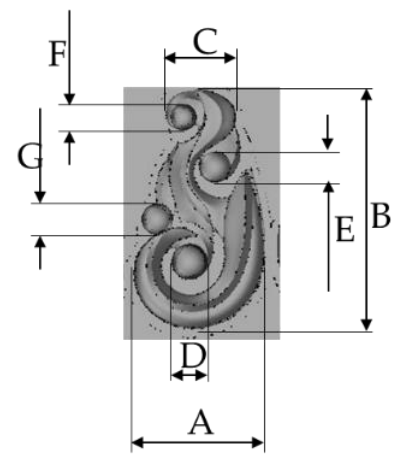

(c)

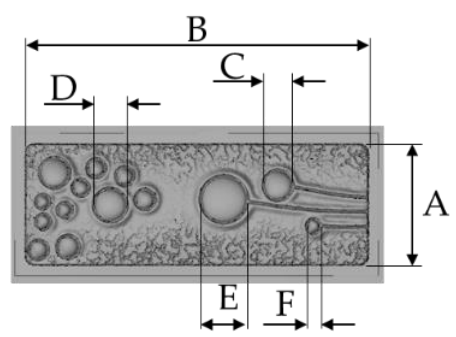

(d)

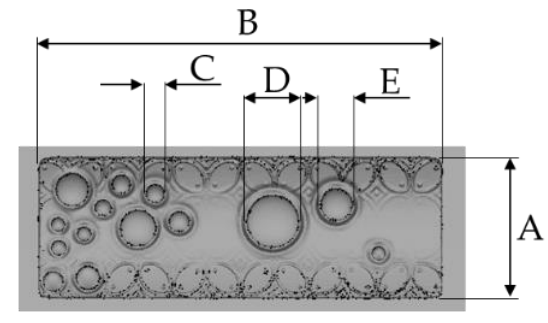

(e)

Figure 6 3D CAD master design model for jewerly ceramic products with Indonesian batik motifs: (a) Geometric Pattern; (b) Geometric Kawung Pattern; (c) megamendung pattern; (d) flora pattern; (e) kawung flora pattern 


\section{RESULT AND DISCUSSION}

White gypsum and liquid clay are used as the base material to make the master mold patterns and ceramic clay to be baked. The choice of these two materials is more based on the characteristics of white gypsum which is easier to absorb water and liquid clay is easier for the casting process.

Clay is a material that is usually used as a base for making ceramics. Clay itself has several main ingredients including kaolinite, halloysite, montmorillinote and illite. The plastic properties of clay are used as a base for making ceramics with various motives. Another property of clay is that it can absorb water and can go through a combustion process with temperatures between $1150^{\circ} \mathrm{C}$ to $1250^{\circ} \mathrm{C}$. Clay-based ceramics, if they have gone through the combustion process, tend to have a rough texture, are brittle and have pores so that further steps are needed such as coating using cement or glaze so that the results can be waterproof. The material used in this study is liquid clay which can fill the entire contents of the mold and can harden according to the shape of the mold. The clay used in this study was not mixed with other ingredients.

The master mold pattern which is often known as core and cavity in this paper is done manually by the mold engineer at the PT GKI mold department. Based on the stages of the mold pattern master manufacturing process in Figure 3, the average processing time for this pattern master ranges from 1-2 days of processing. However, this work can also be done using a computer aided reverse engineering system technology with a CNC machine. The result is a variation of the ceramic jewelry mold pattern with a free angle of $800-850$, as has been done by [8] when designing, manufacturing and fabricating Islamic Tile Wall puzzles at the Al Huda Mosque, Jakarta, Indonesia. This liberating angle, deliberately made so that after pouring the liquid clay material dries, hence the clay can be removed easily without damaging the ornament relief that has been machined in a CNC router machine by previous researchers [10]. The clay that has been removed from the mold pattern is then measured to see the difference in size dimensions in the predetermined area so that it can be calculated how much dimensional error is obtained (Table 1).

This paper is about the manufacturing process and fabrication of ceramic jewellery with Islamic ornaments and Indonesian batik. Islamic ornament is an element that unites architecture and religion that can produce tranquillity, can be understood, structured, and high spiritual from Islamic art and architecture and displays many elements of flora [11]. Geometry in Islamic art and architecture and Indonesian batik also creates archetypes in design. Unique lines that weave like weaving into various patterns show a wonderful imagination and have inventive value [12]. The multiplication of each geometric pattern of architectural elements at different scales in one plane also helps avoid sharp contrasts and clear definitions of scale and surface [11].

Based on Table 1 above, it can be seen that each indicator has a different percentage and error dimension. Factors that influence this are the condition and quality of the soil, the condition of the mold, the temperature and position of the object during the combustion process. By using a tilt angle of $800^{\circ}$, a shrinkage percentage is obtained for a patterned pendant product.

\section{CONCLUSION}

The application of technology design, manufacture and fabrication of ceramic jewerly pendants with Indonesian batik motifs was successfully carried out in this paper by producing 5 motifs and jewerly necklace products that are ready to be marketed by Naruna Ceramic Studio, Salatiga, Central Java. The research results show that the use of this technology is able to produce products according to the standards set by the factory at a maximum of $12 \%$ for shrinkage and the average error dimension for all products is a maximum of $1.50 \mathrm{~mm}$.

Future research will be directed to the innovation of ceramic tableware products with Indonesian batik motifs using artistic CAD/CAM technology with a CNC machine (dining set tableware, bowls, mugs, gels, and saucers).

\section{ACKNOWLEDGMENT}

Thank you LPPM Diponegoro University for the support of research funds in the activities of PKUM also CV. Sibad Engineering and Naruna Ceramics Studio which aids in the procurement of materials and equipment that can be used to do ceramic fabrication with indonesian batik motives. 
Table 1. Measurement Results and Depreciation Percentage from Clay to Combustion Products in Indonesian Batik Patterned Ceramic Jewelry Products

\begin{tabular}{|c|c|c|c|c|c|c|c|c|c|}
\hline $\begin{array}{l}\text { Product } \\
\text { Patterned } \\
\text { Pendants } \\
\end{array}$ & Indicator & $\begin{array}{l}\text { Master } \\
\text { Product } \\
(\mathrm{mm}) \\
\end{array}$ & $\begin{array}{l}\text { Mold } \\
(\mathbf{m m})\end{array}$ & Clay (mm) & $\begin{array}{l}\text { Burn } \\
\text { Result } \\
(\mathbf{m m}) \\
\end{array}$ & $\begin{array}{c}\text { Shrinkage } \\
(\%)\end{array}$ & $\begin{array}{c}\text { Error } \\
\text { Dimension } \\
(\mathrm{mm}) \\
\end{array}$ & $\begin{array}{c}\text { Average } \\
\text { Shrinkage }\end{array}$ & $\begin{array}{c}\text { Average } \\
\text { Error } \\
\text { Dimension } \\
\end{array}$ \\
\hline \multirow{8}{*}{$\begin{array}{l}\text { Geometric } \\
\text { Pattern }\end{array}$} & $\mathrm{A}$ & 34.1 & 34.5 & 34.3 & 32.7 & 4,6 & 1.6 & \multirow{8}{*}{4,1} & \multirow{8}{*}{0.6} \\
\hline & $\mathrm{B}$ & 60.2 & 60.5 & 60.4 & 59.4 & 1.7 & 1.0 & & \\
\hline & $\mathrm{C}$ & 11.7 & 13.1 & 13.2 & 12.6 & 4,8 & 0.6 & & \\
\hline & $\mathrm{D}$ & 14 & 14.9 & 14.6 & 13.7 & 6.5 & 0.9 & & \\
\hline & $\mathrm{E}$ & 7,1 & 7.4 & 7.3 & 7,1 & 2.9 & 0.2 & & \\
\hline & $\mathrm{F}$ & 5,2 & 6.3 & 5.8 & 5.7 & 2,4 & 0.1 & & \\
\hline & G. & 5,4 & 6,7 & 6.3 & 6.0 & 4,6 & 0.3 & & \\
\hline & Thick & 7,8 & 8.3 & 7,8 & 7.4 & 5.1 & 0.4 & & \\
\hline \multirow{5}{*}{$\begin{array}{l}\text { Kawung } \\
\text { Geometric } \\
\text { Pattern }\end{array}$} & $\mathrm{A}$ & 34.4 & 34.6 & 34.4 & 31.9 & 7.3 & 2.5 & \multirow{5}{*}{6.6} & \multirow{5}{*}{0.9} \\
\hline & $\mathrm{B}$ & 10.3 & 11.2 & 11.1 & 10.4 & 6.4 & 0.7 & & \\
\hline & $\mathrm{C}$ & 6.1 & 6.2 & 5.8 & 5.5 & 5,6 & 0.3 & & \\
\hline & $\mathrm{D}$ & 4,7 & 4,4 & 4,2 & 3,9 & 7.4 & 0.3 & & \\
\hline & Thick & 7,6 & 7.3 & 6.6 & 6.2 & 6.5 & 0.4 & & \\
\hline \multirow{8}{*}{$\begin{array}{l}\text { Megamendung } \\
\text { Pattern }\end{array}$} & $\mathrm{A}$ & 34.2 & 34.7 & 33.8 & 32.6 & 3,6 & 1,2 & \multirow{8}{*}{2,4} & \multirow{8}{*}{0.5} \\
\hline & $\mathrm{B}$ & 63.5 & 64.5 & 63.9 & 62.8 & 1.7 & 1,1 & & \\
\hline & $\mathrm{C}$ & 18.7 & 19.7 & 18.8 & 18.2 & 3,2 & 0.6 & & \\
\hline & $\mathrm{D}$ & 9,2 & 10.4 & 9.7 & 9.4 & 2.8 & 0.3 & & \\
\hline & $E$ & 8.9 & 9.5 & 9,2 & 9.0 & 1.7 & 0.2 & & \\
\hline & $\mathrm{F}$ & 6.6 & 7,8 & 7,2 & 7,1 & 1.7 & 0.1 & & \\
\hline & G. & 8.8 & 9,2 & 8.9 & 8.7 & 2.0 & 0.2 & & \\
\hline & Thick & 9,2 & 10.3 & 9.5 & 9.3 & 2,6 & 0.2 & & \\
\hline \multirow{7}{*}{$\begin{array}{l}\text { Flora Pattern } \\
\text { Pattern }\end{array}$} & $\mathrm{A}$ & 36.5 & 36.9 & 36.7 & 33.2 & 9.5 & 3.5 & \multirow{7}{*}{10.0} & \multirow{7}{*}{2.8} \\
\hline & $\mathrm{B}$ & 103.5 & 103.9 & 103.6 & 92.3 & 10.9 & 11.3 & & \\
\hline & $\mathrm{C}$ & 9,2 & 10.4 & 9.8 & 8.9 & 9.6 & 0.9 & & \\
\hline & $\mathrm{D}$ & 9.5 & 11.1 & 10.6 & 9.4 & 11.1 & 1,2 & & \\
\hline & $\mathrm{E}$ & 14.9 & 15.5 & 15.2 & 13.9 & 8.8 & 1.3 & & \\
\hline & $\mathrm{F}$ & 4,2 & 5,6 & 4,9 & 4,3 & 11.8 & 0.6 & & \\
\hline & Thick & 9,1 & 9,2 & 8.9 & 8.1 & 8.6 & 0.8 & & \\
\hline \multirow{6}{*}{$\begin{array}{l}\text { Kawung Flora } \\
\text { Geometric } \\
\text { Pattern }\end{array}$} & $\mathrm{A}$ & 25.7 & 25.8 & 25.5 & 23.3 & 8.8 & 2,2 & \multirow{6}{*}{7,8} & \multirow{6}{*}{1.8} \\
\hline & B & 73.3 & 73.7 & 73.2 & 66.5 & 9,2 & 6,7 & & \\
\hline & $\mathrm{C}$ & 4,4 & 5,2 & 4,6 & 4,3 & 7.0 & 0.3 & & \\
\hline & $\mathrm{D}$ & 10.6 & 11.9 & 10.5 & 10,1 & 3,7 & 0.4 & & \\
\hline & $\mathrm{E}$ & 6.5 & 7.9 & 6.6 & 6.1 & 7.9 & 0.5 & & \\
\hline & Thick & 8.1 & 9,1 & 7,8 & 7.0 & 10.3 & 0.8 & & \\
\hline
\end{tabular}

\section{REFERENCES}

[1] Ministry of Trade of the Republic of Indonesia, "Creative Economy Development Plan". Ministry of Trade RI, 2008.

[2] Ningsih DH. "Computer Aided Design / Computer Aided Manufactur [CAD/CAM]". Journal Teknologi Informasi DINAMIK Volume X, No. 3, September $2005: 143-149,2005$.

[3] Oancea G, Ivan NV, Pescaru R. "Computer-aided reverse engineering system used for customized products". In: Annals of MTeM for 2013 and proceedings of the 11th international MTeM conference, Malaysia, pp 181-186, 2013.
[4] Lopez CI, Pinillos JC, Moreno JC. "Comparison between two design methods implants, based on reverse engineering, design, and engineering technologies, BIO CAN / CAD / CAE". Universidad Industrial de Santander, Escuela de Diseno Industrial, Bucaramanga, Colombia, 2013.

[5] Lang, G. "Ten centuries of decotative ceramic 1000 tiles; 1st edition, Chronicle Books LLC. ISBN: 08118-4235-5, USA, 2004.

[6] Renzi, J. "The art of tile: designing with timehonored and new tiles; 1st edition "Published in the United States by Clarkson Potter / Publisher, an imprint of the Crown publishing Group, a division of Random House, Inc., New York, USA, 2019. 
[7] Anggoro PW, Bawono B, Sujatmiko I. "Reverse engineering technology in redesign process ceramics: application for CNN plate". Procedia Manufacturing. 4, 521 - 527, 2015.

[8] Anggoro PW, Yuniarto AT, Tauviqirrahman M, Jamari J, Bayuseno AP, Purwanto KB and Widyanarka OKW. " Puzzle Islamic Floral Patterns Product Tiles for Wall and Ceiling to Decorate of $\mathrm{Al}$ Huda Mosque Indonesia-Design, Manufacturing, and Fabrication". Proceedings of the 6th International Conference and Exhibition on Sustainable Energy and Advanced Materials ICESEAM, 2019.

[9] Abdullahi, Y, Rashid, M. "Evolution of Islamic geometric patterns. Frontiers of Architectural Research ". Frontiers of Architectural Research 2, 243-251. Faculty of Built Environment, Universiti Teknologi Malaysia, Johor 81310, Malaysia, 2013.
[10] PK Fergiawan, PW Anggoro, AT Yuniarto, KB Purwanto, and ODW Widyanarka. "Ceramic Jewelry with Texture and Ornament Islamic Patterns and Indonesian Batik - Design, Manufacturing, and Fabrication". Proceedings of the 6th International Conference and Exhibition on Sustainable Energy and Advanced Materials ICE-SEAM, 2019.

[11] Othman, HI. "Role of computer aided design and computer aided manufacturing technology in prosthetic implant restorations". International Journal of Dental Clinics, 4 (4), 22-34. ISSN: 09758437, 2012.

[12] Baer, J. "The Case for Domain Specificity of Creativity ". Creativity Research Journal 11 (2): 173-177, 1998 